of yield stability in Pinus tabulaeformis seed orchard. Acta Agriculturae Universitatis Henanensis 30(1): 57-64.

LI, W, X. R. WANG and Y. LI (2011): Stability in and correlation between factors influencing genetic quality of seed lots in seed orchard of Pinus tabulaeformis Carr. over a 12-year span. PloS ONE 6(8): 1-9.

LI, W., X. R. WANG and Y. LI (2012): Variation in Floral Phenological Synchronization in a Clonal Seed Orchard of Pinus tabuliformis in Northeast of China. Silvae Genetica 61(4-5): 133-142.

MATZIRIS, D. (1993): Variation in cone production in a clonal seed orchard of Black pine. Silvae Genetica 42(2-3): 136-141.

MATZIRIS, D. (1998): Genetic variation in cone and seed characters in a clonal seed orchard of Aleppo pine grown in Greece. Silvae Genetica 47(1): 37-41.

NIKKANEN, T. and S. RUOTSALAINEN (2000): Variation in flowering abundance and its impact on the genetic diversity of the seed crop in a Norway spruce seed orchard. Silvae Fennica 34(3): 205-222.

O'ReILly, C., W. H. PARKER and J. E. BARKER (1982): Effect of pollination period and strobili number on random mating in a clonal seed orchard of Picea mariana. Silvae Genetica 31(2-3): 90-94.

Prescher, F., D. Lindgren, C. Almqvist, J. Kroon, T. A. Lestander and T. J. Mullin (2007): Female fertility variation in mature Pinus sylvestris clonal seed orchards. Scandinavian Journal of Forest Research 22: 280-289.

REYNOLDS, S. and Y. A. KASSABY (1990): Parental balance in Douglas-fir seed orchard - cone crop vs. seed crop. Silvae Genetica 39(1): 40-42.
Schoen, D. J., D. Denti and S. C. Stewart (1986): Strobili production in a clonal white spruce seed orchard: evidence for unbalanced mating. Silvae Genetica 35(5-6): 201-205.

Shen, X. H., Y. Li and X. R. WANG (1985): Study on flowering habit of Pinus tabulaeformis Carr in the Seed orchard located in Xingcheng county, Liaoning province. Journal of Beijing Forestry University 3: 1-13.

Sivacioglu, A., S. Ayan and D. A. CeliK (2009): Clonal variation in growth, flowering and cone production in a seed orchard of Scots pine (Pinus sylvetris L.) in Turkey. African Journal of Biotechnology 8(17): 4084-4093.

Tudhunter, M. N. and R. B. PolK (1981): Seed and cone production in a clonal orchard of Jack pine $(P$. banksiana). Canadian Journal of Forest Research 11: $512-516$.

WanG, S. S., X. H. Shen, L. H. YaO, Y. Li, J. G. Li and A. D. LI (1985): A comparative study on growth patterns of Pinus tabulaeformis clones in Xingcheng seed orchard, Liaoning province. Journal of Beijing Forestry University 4: 72-83.

WANG, X. R. and X. H. Shen (1987): Studies on pollen dispersal of Pinus tabulaeformis Carr. in Xingcheng seed orchard located in a mountainous area. Scientia Silvae Sinicae 23(1): 1-10.

WANG, X. R. and X. H. SHEN (1989): Studies on increasing seed production in seed orchards of Pinus tabulaeformis Carr. - An analysis of seed losses caused by arborted ovules and emptied seeds. Journal of Beijing Forestry University 11(3): 60-65.

Zhang, H. X. and X. H. Shen (2002): Progress on reproductive system of forest seed orchards. Scientia Silvae Sinicae 38(2): 129-134.

\title{
Breeding triploid aspen and poplar clones for biomass production
}

\author{
By K. UlRICH*) and D. EwALD ${ }^{1)}$ \\ Johann Heinrich von Thünen-Institute (TI), Federal Research Institute for Rural Areas, \\ Forestry and Fisheries, Institute of Forest Genetics, Waldsieversdorf, Germany
}

(Received 25 $5^{\text {th }}$ June 2013)

\begin{abstract}
Enriched diploid pollen was applied for in vitro pollinations and crossbreeding in the greenhouse to produce high performance triploid aspen and aspen hybrids for cultivation in medium rotation plantations. In addition

$\overline{1) \text { DIETRICH EwALD. E-Mail: dietrich.ewald@ti.bund.de. }}$

*) Corresponding author: KRISTINA UlRICH. Johann Heinrich von Thünen-Institut, Institut für Forstgenetik, Eberswalder Chaussee 3a, D-15377 Waldsieversdorf, Germany. Phone: +49 33433 157-175, Fax: +49 33433 157-199. E-Mail: kristina. ulrich@ti.bund.de.
\end{abstract}

to crossings within the section Populus, intersectional crossbreeding was performed to combine benefits of intersectional hybridization with those derived from triploidisation.

Both the enrichment of diploid pollen by size fractionation of naturally unreduced pollen and heat treatment of microspore mother cells resulted in a distinct increase of diploid pollen. Using this pollen, six triploid plants were obtained from in vitro pollinations and twenty from crossbreeding in the greenhouse. The triploid plants displayed a high variability in growth performance. Two clones from in vitro pollination and five from crossbreeding in the greenhouse were chosen to 
estimate growth characteristics. A first assessment of clone performance in an outdoor container test conducted over one growing season revealed two triploid clones with a same stem height and a significantly increased basal stem diameter in comparison to the fast-growing triploid reference clone "Astria". Crossbreeding experiments also resulted in two fast-growing mixoploid clones, which have already been stable for several years.

All in all, in this study, crossbreeding using enriched diploid pollen is proved to be a reliable and applicable approach for an effective breeding of triploid poplars.

Key words: Populus spp., triploid, in vitro pollination, intersectional crossbreeding, diploid pollen.

\section{Introduction}

Poplars are cultivated extensively in the Northern Hemisphere because of their fast growth, high adaptability and flexibility and widely used wood for industrial timber, fibre and lumber. Moreover, poplars and their hybrids are considered to be the premier woody perennial candidate for bioenergy feedstock production (DE LA Torre Ugarte et al., 2003; Perlack et al., 2005). They offer several agronomic and logistical advantages, e.g.: (i) Poplars are the fastest growing tree species within the temperate zone with biomass growth rates of current varieties approximating 10-15 dry $\mathrm{Mg} \mathrm{ha}^{-1} \mathrm{yr}^{-1}$ on four year rotations (STANTON et al., 2002; RIEMENSCHNEIDER et al., 2001). (ii) Biomass can be stored on the stump and regenerated by coppicing, minimizing the investment in storage facilities (WRIGHT, 1994). (iii) The net effect of poplar cropping systems on greenhouse gas emissions compares very favourably to those of other cellulosic crops owing to their less frequent tillage and cutting cycles (ADLER et al., 2007).

The genus Populus is made up of six sections, three of which - Aigeiros (cottonwoods), Tacamahaca (balsam poplars), and Populus (white poplars and aspens) - are especially important for biomass production in temperate regions and account for nearly the world's entire applied breeding work (STANTON et al., 2010, JANSSEN et al., 2012). Recently, many efforts have been made to breed poplars with higher growth potential and resistance against abiotic and biotic stress factors for biomass plantations. One promising approach for the improvement of poplars is the breeding of rapid-growing triploid clones showing appropriate resistance and tolerance characteristics. Natural or induced triploid aspen and poplars often have certain growth and fiber characteristics that are superior to diploid forms (SCHLARBAUM, 1991). The first naturally occurring triploid aspen (P. tremula, section Populus, former Leuce) was discovered in Sweden in 1934 (NILSSON-EHLE, 1936) and described as a tree of larger-than-normal size with large, dark-green leaves (giant form). MüNTZING (1936) confirmed the triploid state by chromosome counts. In North America, the large size and apparent rapid growth of natural triploids attracted the attention of breeders and lead investigators to search for triploid fast-growing aspen. The first North American triploid quaking aspen (P. tremuloides) were found in northeastern Minnesota (VAN BuIJTENEN et al., 1957; EINSPAHR et al., 1963) and later in Utah (EvERY and WIENS, 1971). In recent studies, high rates of triploidy (up to $69 \%$ of genets) were demonstrated in $P$. tremuloides across the western USA (Mock et al., 2012). Natural well-growing triploids of Populus tomentosa were first discovered in China (ZHU et al., 1998; YAO and PU, 1998).

With the discovery and subsequent evaluation of goodquality, rapid growing triploid trees, there was an increasing interest in methods suitable and effective for breeding of commercially usable triploid clones which can be applied for the paper and wood industry (EINSPAHR and WINTON, 1976; EINSPAHR, 1984). Research in polyploidy gained in importance as a promising improvement tool, especially in aspen breeding, and different methods of polyploidy-breeding have been tested over the years:

\section{Tetraploid-diploid crosses}

By crossing artificially produced tetraploid with diploid trees, fast-growing triploids could be obtained from different tree species, and this strategy seemed to be very promising, especially for aspen (BAUMEISTER, 1980). Triploid hybrid aspen were produced in numbers for the first time in 1958 by crossing highly selected diploid female $P$. tremuloides clones with a single male tetraploid $P$. tremula of Swedish origin. The growth rate of these hybrids was significantly higher compared with native aspen, and the trees had higher wood density, longer fiber length, and improved pulp properties (EINSPAHR, 1984). By crossing a tetraploid P. tremula with pollen of a diploid Canadian $P$. tremuloides, the fast-growing triploid hybrid aspen clone "Astria" was produced (BAUMEISTER, 1980). This clone has proven successful over a long time and is still grown today, especially in maxi-rotation plantations.

A controlled production of valuable tetraploid plants as parent for breeding of triploids can be achieved by the application of the alkaloid colchicine, which disrupts mitosis by binding to tubulin, resulting in cells with doubled number of chromosomes. Colchicine has been used for the production of tetraploids in different woody plants (VÄINÖLÄ, 2000; LIU et al., 2007; TANG et al., 2010). For poplar, tetraploid induction using colchicine treatment has been reported for the sections Populus (EwALD et al., 2009) and Tacamahaca (CAI and KANG, 2011).

\section{Use of diploid gametes}

Naturally occurring triploids result from the fertilization of normal haploids (n) with unreduced, diploid (2n) gametes (HEILBORN 1934; HARLAN and DE WET, 1975). The frequency of spontaneous production of unreduced gametes in natural plant populations may be influenced by genetic and environmental variables (SAX, 1936; SkIEBE, 1965; HARLAN and DE WET, 1975; KANG, 2002). The most common method of breeding triploid plants is the application of spontaneous or induced diploid pollen. In the genus Populus, spontaneous occuring $2 \mathrm{n}$ pollen has been found in $P$. tremula (MüNTZING, 1936), $P$. nigra (KANG, 2002) and P. tomentosa (ZHU et al., 1998), however, the natural occurrence rate of diploid pollen in 
poplar is generally low (below $5 \%$, $\mathrm{XI}_{\mathrm{I}}$ et al., 2011). There have been many reports on the artificial induction of diploid pollen in various tree species by treating their male generative buds with different agents such as high temperature, colchicine and $\mathrm{N}_{2} \mathrm{O}$ (reviewed in DEwITTE et al., 2012). For poplars, the artificial induction of diploid pollen is an essential technique for polyploid breeding. JoHNSSON and ECKLUNDH (1940) first induced diploid pollen of $P$. tremula and $P$. tremuloides using colchicine and produced triploid plants by pollinating female catkins of diploid plants with artificially induced $2 \mathrm{n}$ pollen. MASHKINA et al. (1989) investigated mechanisms of $2 \mathrm{n}$ pollen formation in different Populus species exposed to $38-40^{\circ} \mathrm{C}$ during microsporogenesis. Triploids have also been induced by chromosome doubling of pollen of Chinese white poplar ( $P$. tomentosa) and $P$. tomentosa x $P$. bolleana using colchicine and other chemical agents (ZHU et al., 1997; KANG et al., 1999; KANG et al., 2006). Whereas most inductions of $2 \mathrm{n}$ pollen in poplar focused on the species in section $Р$ Рориlus, XI et al. (2011) induced diploid pollen in $P$. х popularis using colchicine and opened the way for polyploidy breeding in sections Aigeiros and Tacamahaca.

Reports on triploid production via induction of $2 \mathrm{n}$ eggs are rare in Populus, because it is difficult to determine the exact stage of megasporogenesis, which processes inside of ovules of a whole flower (WANG et al., 2010). However, based on the analysis of the temporal relationship between megasporogenesis and microspore development which allowed the optimal time for colchicine treatment to be determined, LI et al. (2008) obtained up to $16.7 \%$ triploid plants by inducing unreduced megaspores at the prophase of the first meiotic division in $P$. alba x $P$. glandulosa. Diploid eggs were also induced by treatment of developing embryo sacs both with colchicine and high temperature. A method for $2 \mathrm{n}$ egg induction by treatment of developing embryo sacs with colchicine and alternatively with high temperatures was described for P. pseudosimonii x P. nigra (WANG et al., 2010 and 2012).

If diploid pollen is planned for use in ploidy breeding, it must be correctly identified. Detection can follow with flow cytometric detection of pollen DNA content, analyses of the microsporogenesis, ploidy analysis of the progeny and pollen size measurement (BRETAGNOLLE and Thompson, 1995). Because the diameter of pollen grains may become larger due to the doubling of chromosome numbers, pollen size has been widely used as an indicator of $2 \mathrm{n}$ male gametes (VEILLEUX et al., 1982; ORJEDA et al., 1990; ORTIZ, 1997). Based on this approach, in different poplar species diploid pollen grains could be distinguished from haploid pollen by microscopic screening (MASHKINA et al., 1989; KANG and ZHU, 1997; ZHU et al., 1998; ZHANG and KANG, 2010).

All in all, several tools seem possible for a successful breeding of triploid plants. However, beside the difficulties in obtaining triploid plants it should be pointed out that fast-growing trees are often triploid, but only a range of triploids are fast-growing. Therefore, the production of triploids needs to be combined with a suitable selection of clones with the requested properties.
The aim of this study was to establish reliable and applicable methods to both the breeding and the selection of high performance triploid aspen, aspen hybrids and poplar clones with favourable growth suitable for cultivation in medium rotation plantations. In order to produce triploid trees, pollen with a higher proportion of diploid pollen grains was obtained by size fractionating of native pollen and artificial induction of unreduced gametes. The enriched diploid pollen was applied for in vitro pollination and crossbreeding in the greenhouse. Intersectional crossings were included to improve growth performance, resistance and tolerance characteristics. Selection of triploids with improved growth characteristics was performed under outdoor conditions.

\section{Materials and Methods}

\section{Plant material}

As female parents the $P$. tremula clone L 316 and the P. tremula x P. tremuloides clones L 40, L 328, L 290 and ARB 4 were used. The $P$. deltoides clone S 39 (section Aigeiros) was included for the intersectional crosses (LIESEBACH et al., 2011).

As male partners, the $P$. tremula clones L 2, L 311, L 9, the $P$. tremula x $P$. tremuloides clone ARB 2M, the grey poplar clones L 449 and L 454 (Populus x canescens), the clone "Androscoggin" (P. maximowiczii x P. trichocarpa) of section Tacamahaca and the $P$. deltoides clone S 13 belonging to section Aigeiros were used. Additionally, pollen of $P$. simonii clone Sim1 (section Tacamahaca) was applied, which was obtained from Prof. Yang (Hebei Agricultural University, China) and originates from the Tongliao Research Institute (Inner Mongolia). All clones used for crossbreeding are diploid. The crossing combinations performed in this study are listed in Tables 2 and 3, respectively.

For evaluation of growth characteristics under outdoor conditions, the fast-growing diploid $P$. tremula clones Brauna 11 and L 291, and the P. tremula $\mathrm{x}$ $P$. tremuloides clone Esch 5 were used as a reference (clone collection Thünen Institute for Forest Genetics). These clones were selected according to growth and stem straightness and tested over many years on different trial plots. Additionally, the triploid clone "Astria" (P. tremula $\times$ P. tremuloides), the performance of which has been proven successfully over a long time in Germany (BAUMEISTER, 1980), was included as reference clone.

\section{Measurement of pollen grain diameter}

Pollen grains were placed on a microscope slide and stained with $2 \%$ aceto-carmine solution allowing better measurement ability in a swollen state. The diameter of pollen grains was determined under the light microscope BH2-RFCA (Olympus) using Imaging Software Cell B (Olympus). At least 150 pollen grains of all male clones used in this study were measured to estimate mean diameter. Test of normal distribution of unreduced haploid pollen grain diameter by the Shapiro-Wilk normality test failed for three of the nine plant clones studied. Therefore, differences between the clones were test- 
ed by the Kruskal-Wallis Analysis followed by post-hoc determination of mutual differences (pgirmess package of $\mathrm{R}$ statistical software vers. 2.15.3 ( $\mathrm{R}$ Core Team, 2013)).

We calculated the ratio of the diameter of diploid and haploid pollen starting from the assumption that pollen grains have a spherical shape and a division of the pollen mother cell leads to either two or four pollen cells. Based on a given and fixed volume of the pollen mother cell, the volume of diploid pollen is double that of haploid pollen cells which results in a ratio of $1.26: 1$ for the diameter of diploid vs. haploid pollen. Mean diameter of haploid pollen grains was multiplied with this factor to obtain the putative mean size of diploid pollen.

\section{Enrichment of natural occurring diploid pollen}

Unreduced diploid pollen, which is larger in size than normal haploid pollen, was enriched from natural pollen mixtures from single trees by fractionation using a vibratory sieve shaker containing a combination of different metal sieves as described by EWALD and ULRICH (2012). For plants with smaller pollen (diameter below $38 \mu \mathrm{m}$ for the calculated size of $2 \mathrm{n}$ pollen), fractions ranging from 32 to $45 \mu \mathrm{m}$ were collected and for plants with larger pollen fractions of 36 to $45 \mu \mathrm{m}$ (Table 1). These fractions were assumed as enriched diploid pollen and used for crossings to produce triploid plants.

\section{Induction of unreduced diploid pollen}

Heat treatment of microspore mother cells (MMCs) and chromosome doubling using colchicine were performed to induce the production of unreduced diploid pollen. The prophase I of meiosis (diakinesis for temperature and pachytene for colchicine treatment) was found to be the optimal stage of microsporogenesis in Populus tomentosa x P. bolleana (KANG et al., 1999, 2000a). Branches from male clones were placed in vessels with tap water in the greenhouse. We checked at least five catkins (middle part of the catkin) to estimate their stage of development when the flower buds opened and one fifth to one fourth of the bud was out of the bud bracts. The anthers were dissected from the buds and squashed in a droplet of aceto-carmine solution (2\%) onto a microscope slide. Developing MMCs were analysed in detail for their sporad stage under a microscope. Heat and colchicine treatment were applied when most of MMCs in one flower started to lose their angles and become round (pachytene).

For heat treatment, branches with male flowers of clones L 2 (Table 2) and L 9 (Table 3) were incubated at $38^{\circ} \mathrm{C}$ for three hours at the early phase of meiosis (prophase I) to induce diploid pollen grains according to MASHKINA et al. (1989).

For colchicine induction of pollen chromosome doubling, the colchicine solution $(0.1 \%)$ was injected into the branches directly under the flowers. The solution was stained with Coomassie's blue to trace the uptake of the solution by the plant into the flower axis.

For both methods the branches were cultured afterwards until complete pollen development was observed.
After the release, the pollen grains were collected, air dried for two days (HERMANN, 1976) and stored at $4^{\circ} \mathrm{C}$ above silica gel under vacuum or frozen at $-20^{\circ} \mathrm{C}$ under vacuum.

\section{In vitro pollination using selected pollen}

In vitro pollination allowing the targeted application of single, selected pollen grains under dry conditions was applied as described by EwALD and ULRICH (2012). Briefly, ovaries with receptive stigmata were prepared from the female flowers and placed in petri dishes with basal salt medium (ScHENK and HiLDEBRANDT, 1972) under the stereo-zoom microscope. About 100 ovaries were prepared for each crossing (Table 2). Using a single hair from a Chinese paint brush, a few pollen grains from the sieved pollen fractions with enriched diploid pollen were carefully transferred onto the stigma. In this way, an additional size-selection of pollen was performed under the microscope during the in vitro pollination by picking the larger pollen grains from the sieveselected fractions. About two weeks after pollination, the ovaries containing developing seeds were opened using a micro scalpel and the zygotic embryos were extracted. Embryos were germinated on nutrient medium until it was possible to transfer them in sterile vermiculite saturated with basal salt medium and later to propagation soil. Triploid plants were selected after 8 weeks by flow cytometry (see below).

\section{Pollination with selected pollen in the greenhouse}

For crossings in the greenhouse (listed in Table 3), which were carried out during the winter months of the respective years, the female clones were placed in vessels with tap water in greenhouse cabins to force flower development. The flowers were observed continuously until the optimal development for pollination was reached. The pollination was performed using sieved fractions from native, heat-treated or colchicine-induced pollen (Table 3) immediately after sampling or after storage at $-20^{\circ} \mathrm{C}$ under vacuum. Pollinated flowers were checked continuously for their development. Female inflorescences were fully developed after about two weeks and the seeds were harvested after their release.

In spring of the following year, the seeds were sown in mini-greenhouses on vermiculite saturated with a basal salt medium (SCHENK and HILDEBRANDT, 1972) and placed under a light regime of $16 \mathrm{~h}$ white light and $23^{\circ} \mathrm{C}$. After about 8 weeks, the seedlings were transferred to propagation soil in Quickpot containers and grown in the greenhouse with additional light. Approximately three months after sowing, the selection of triploids was performed by flow cytometry (see below). Triploid seedlings found were transplanted into containers for further growing and subsequently transferred into the nursery. The best performing plants concerning shoot height and basal stem diameter (BSD) were micropropagated for outdoor testing.

\section{Flow cytometry for analysis of ploidy level}

We used flow cytometry to select triploid plants from the in vitro pollination and crossbreeding in the greenhouse. Approximately $0.5 \mathrm{~cm}^{2}$ leaf tissue was used for 
the preparation and staining of nuclei suspension with the CyStainUV preciseP reagent kit (Partec $\mathrm{GmbH}$, Münster, Germany) according to the manufacturer's instructions. For ploidy assessment, the fluorescence of stained nuclear DNA was analysed with a CyFlow ploidy analyser (Partec $\mathrm{GmbH}$ ) according to EwALD et al. (2009). Samples were analysed in comparison with material from diploid, triploid (clone "Astria") or tetraploid control plants as an internal standard to confirm ploidy level.

\section{In vitro propagation of plants for the outdoor tests}

Triploid plants derived from in vitro pollinations were propagated in vitro on a modified Linsmaier-Skoog medium (LINSMAIER and SKOOG, 1965) for maintenance and as plant material for the outdoor tests. The cultures were kept at $23^{\circ} \mathrm{C}$ with a $16 \mathrm{~h}$ photoperiod supplied by warm-white fluorescent light at $30-40 \mu \mathrm{E} \mathrm{m} \mathrm{m}^{-2} \mathrm{~s}^{-1}$. From the triploid and mixoploid seedlings derived from pollinations in the greenhouse, plantlets were re-established in vitro and maintained on an appropriate regeneration medium. All clones to be compared in the outdoor test were propagated in a similar manner and at a similar time to have the same preconditions and age.

\section{Container test for estimation of growth properties}

For a fast estimation of the growth properties of the triploid clones in comparison to other aspen and poplar clones, in vitro propagated plants were transferred to Quickpot containers (containing 12 plants) with propagation soil at the end of March 2012. Several years of experience demonstrate the suitability of container tests for an initial evaluation of clone performance (stem height and BSD after one growth period). Additionally, a subsequent transplanting to the field is possible for further testing.
Plants were grown in the greenhouse under additional light and transferred to the nursery in May. The final height and BSD was measured at the end of September, about 6 months after planting. Forty-eight individuals were tested for each clone. The Shapiro-Wilk normality test failed; accordingly, significance of differences was tested by the Kruskal-Wallis Analysis followed by posthoc determination of mutual differences ( $R$ statistical software).

\section{Results and Discussion}

\section{Enrichment and induction of unreduced diploid pollen}

For all male clones used in the crossings, the average size of native pollen was determined microscopically. The mean diameters of the haploid pollen of the different clones ranged from 28.8 to $34.5 \mu \mathrm{m}$ (Table 1). The clones belonging to section Populus revealed large clone specificity with significant differences between several clones, e.g., $P$. x canescens L 454 vs. $P$. tremula L 2 and L 9 but also vs. $P$. x canescens L 449. The diameter of pollen grains of $P$. deltoides $\mathrm{S} 13(32.7 \mu \mathrm{m})$, belonging to section Aigeiros, was significantly different from $P$. simonii Sim 1 and clone "Androscoggin", both belonging to section Tacamahaca. However, differences in pollen size are not generally associated with species or section assignment.

Based on the assumption that diploid pollen grains are generated by a disturbed meiosis (formation of only two instead of four pollen cells), diploid spherical pollen cells should have a double volume and therefore, according to mathematical calculation, a 1.26-fold diameter. This assumption is supported by results of DE STORME and GEeLEN (2011), which revealed a ratio of $1: 1.28$ for haploid vs. diploid Arabidopsis pollen (21.5:27.5 um) after measuring. Accordingly, the diploid pollen of aspen

Table 1. - Pollen sizes of aspen- and poplar clones used as male partners.

\begin{tabular}{|c|c|c|c|}
\hline Clones & $\begin{array}{c}\text { Mean diameter of } \\
\text { haploid pollen } \\
(\mu \mathrm{m})^{*}\end{array}$ & $\begin{array}{l}\text { Calculated diameler } \\
\text { of diploid pollen } \\
\qquad(\mu \mathrm{m})^{* *}\end{array}$ & $\begin{array}{l}\text { Sieve fraction used } \\
\text { for selection of } \\
\text { diploid pollen }(\mu \mathrm{m})\end{array}$ \\
\hline $\mathrm{L} 2(P$. tremula $)$ & $29.67 \pm 0.19 c, d$ & 37.38 & $32-45$ \\
\hline L 311 (P. tremula) & $32.80 \pm 0.15 a, b$ & 41.33 & $36-45$ \\
\hline L $9(P$. tremula $)$ & $30.20 \pm 0.23 c$ & 38.05 & $36-45$ \\
\hline ARB $2 \mathrm{M}$ (P. tremula $\times$ P. tremuloides) & $32.61 \pm 0.17 b$ & 41.09 & $36-45$ \\
\hline $\mathrm{L} 449$ (P. x canescens) & $29.87 \pm 0.15 c . d$ & 37.63 & $32-45$ \\
\hline $\mathrm{L} 454$ ( $P . x$ cantescens) & $34.48 \pm 0.27 a$ & 43.44 & $36-45$ \\
\hline $\begin{array}{l}\text { "Androscoggin" (P. maximowiczii } x P \text {. } \\
\text { trichocarpa) }\end{array}$ & $28.75 \pm 0.26 d$ & 36.22 & $32-45$ \\
\hline Sim 1 (P. simonii) & $29.77 \pm 0.12 c, d$ & 37.51 & $32-45$ \\
\hline S 13 (P. deltoides $)$ & $32.73 \pm 0.26 b$ & 41.24 & $36-45$ \\
\hline
\end{tabular}

* Diameter is given as mean \pm standard error of mean. Different letters indicate significant differences between the clones $(\mathrm{p}<0.05)$.

** The diameter of diploid pollen was calculated by multiplying the haploid pollen diameter by the factor of 1.26 . 


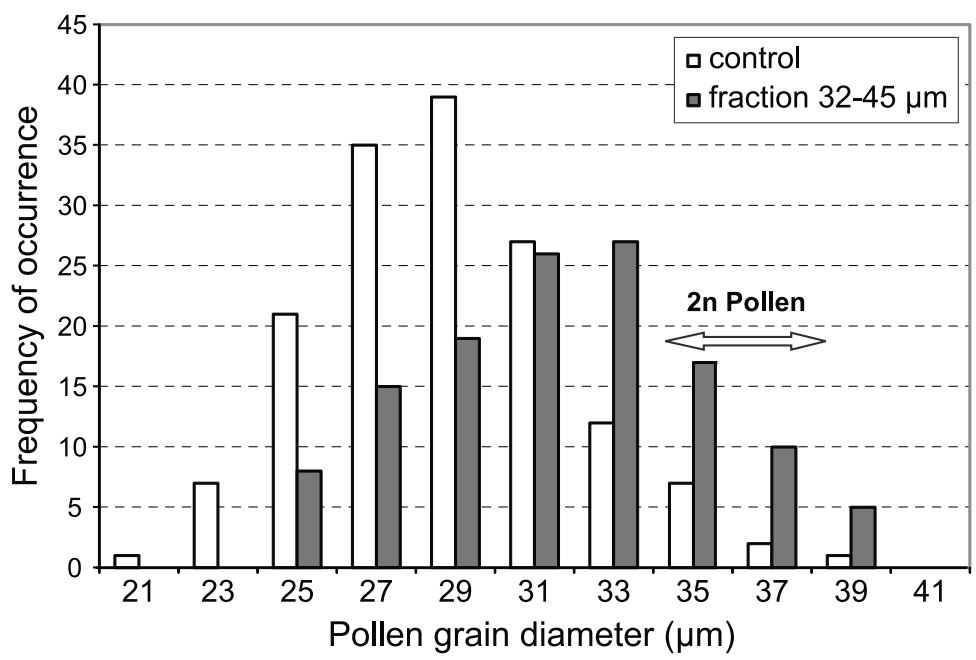

Figure 1. - Enrichment of diploid pollen grains from native pollen of the clone "Androscoggin" using a vibratory sieve shaker. The grey columns represent the pollen fraction resulted from sieving using metal sieves with mesh sizes of 32 and $45 \mu \mathrm{m}$ containing enriched unreduced diploid pollen. The white columns indicate the untreated pollen.

and poplar clones should have a mean diameter ranging from 36.2 to $43.4 \mu \mathrm{m}$, depending on the size of haploid pollen (Table 1). To enrich spontaneous induced diploid pollen from natural pollen mixtures, sieve fractions from 32-45 $\mu \mathrm{m}$ were used for pollen smaller in diameter (below $38 \mu \mathrm{m}$ for the assumed size of diploid pollen), for example from clone "Androscoggin" and P. tremula L 2, and sieve fractions from 36-45 $\mathrm{um}$ for larger pollen (e.g., from $P$. deltoides S 13 and L 454).

The frequency distribution of pollen grain diameter of a pollen fraction resulted from sieving using micro sieves $(32-45 \mu \mathrm{m})$ in comparison to native pollen is exemplarily presented for the clone "Androscoggin" in Figure 1. Sieving resulted in a distinct shift of the frequency distribution to larger pollen with a clear increase of size classes of $33 \mu \mathrm{m}$ and above. As the putative size of the diploid pollen of this clone was calculated with $36.22 \mu \mathrm{m}$, diploid pollen was obviously enriched. Proceeding from the assumption that the majority of diploid pollen has the size of $36.22 \pm 2 \mu \mathrm{m}$, the proportion of diploid pollen was increased from $4.6 \%$ to $19.7 \%$ by sieving.

Another approach to enhance the amount of diploid pollen is the artificial induction of unreduced diploid pollen by heat-treatment or colchicine application. Generation of diploid pollen was induced by heat-treatment at $38^{\circ} \mathrm{C}$ for three hours at the early phase of meiosis. In the two male $P$. tremula clones L 2 and L 9, the proportion of large putative diploid pollen grains was considerably increased after treatment. A microscopic comparison of the pollen sizes obtained after heat-treatment is demonstrated in Fig. 2 exemplarily for clone L 9. Two clearly different size classes are visible which correspond to haploid and diploid pollen. The frequency distribution of pollen grain diameter for the $P$. tremula clone L 9 after treatment at $38^{\circ} \mathrm{C}$ compared to untreated pollen is shown in Fig. 3. Heat treatment resulted in a formation of two clear maxima. The first peak repre- senting the haploid pollen shows a small shift in grain diameter as compared to the untreated pollen. The second peak in the histogram of the treated sample represents the unreduced diploid pollen. The size ratio of pollen grain diameter of both maxima corresponded well with the calculated ratio of 1:1.26 for haploid (1n) to diploid (2n) pollen. For a further enrichment of the heatinduced diploid pollen grains, the pollen sample was sieved to separate the fraction of 36-45 $\mu \mathrm{m}$.

Heat treatment of pollen mother cells could be effectively applied just in two cases, for the P. tremula clones L 9 and L 2. For the other male clones, this method was

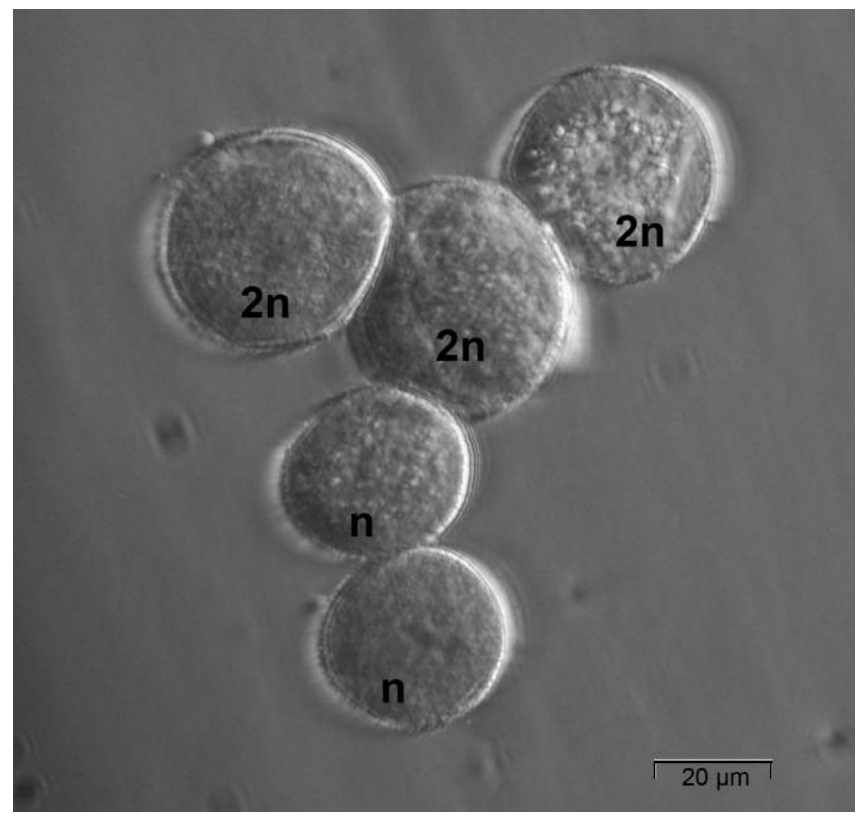

Figure 2. - Aceto-carmine stained pollen grains of the $P$. tremula clone L 9 after heat treatment for three hours at $38^{\circ} \mathrm{C}$ at the early phase of meiosis. " $2 n$ " indicates the unreduced and " $n$ " the reduced pollen. 


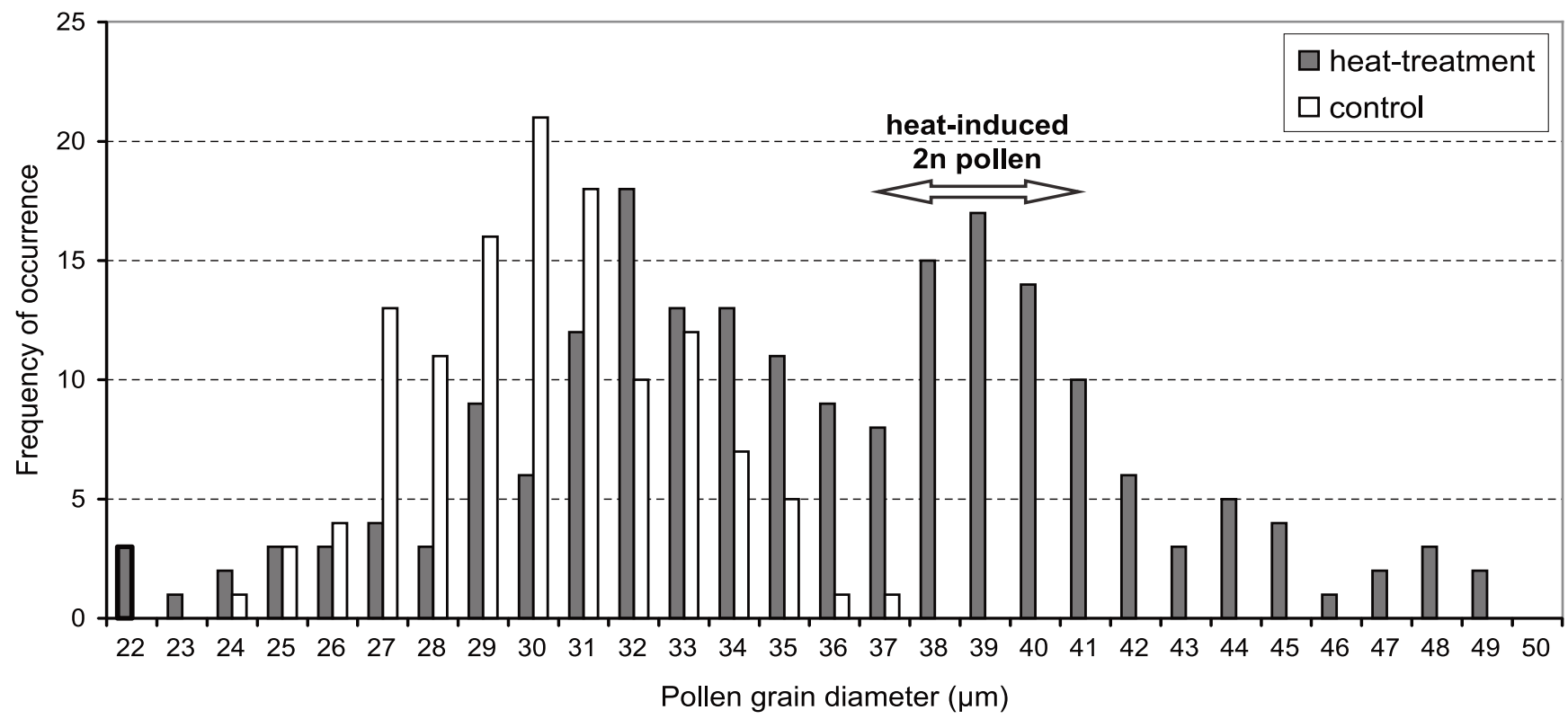

Figure 3. - Frequency distribution of pollen grain diameter of the P. tremula clone L 9 after heat-treatment in comparison to untreated pollen.

not successful or it was only possible to generate a very low amount of diploid pollen. The pitfalls of this technique are a number of factors important for an effective induction of pollen chromosome doubling and the pollen release afterwards, such as the optimal time of induction (state of meiosis), duration of treatment and temperature used for induction (MASHKINA et al., 1989; KANG et al., 1999; ZHANG and LI, 1992). Additional problems arise from the different behaviour of germination between haploid and diploid pollen.

\section{Production of triploid plants using in vitro pollination}

In vitro pollination using enriched diploid pollen was carried out in a period of four years (Table 2). Altogether, six crossing combinations were performed; five using enriched spontaneous induced $2 \mathrm{n}$ pollen from natural pollen mixtures and one using heat-induced $2 \mathrm{n}$ pollen (Table 2). In total, six triploid clones were generated from single plants selected from these experiments. Three of them, "Tripi", "Trio" and L 328 x L 449 No. 1 could be propagated successfully in vitro. The first two clones were chosen for the container test in the nursery (see below). The triploid plants derived from the other crossings were very small, in the case of ARB $4 \mathrm{x}$ ARB 2M possibly caused by inbreeding. Therefore, propagation in tissue cultures did not seem to be very promising. In general, the recovery of triploid plants was relatively low using the in vitro technique. The percentage of triploid plants per total number of ovaries used ranged from $0.4 \%$ to $1 \%$. Maybe the efficiency of the method could be enhanced by further increasing the amount of diploid pollen grains in the pollen mixtures used for the experiments. Since the in vitro pollination is also very elaborate it should be applied mainly for special crossings, for example, if the quantity of pollen is limited. Furthermore, the method may be helpful for crossings with incompatible partners requiring embryo rescue under continuous observation.

\section{Production of triploid plants by crossbreeding in the greenhouse}

Out of the seven crossings with enriched diploid pollen performed in the greenhouse, five triploid offspring individuals derived from aspen and fifteen triploids from intersectional poplar crosses could be produced (Table 3). In 2011, three triploid plants (No. 3, 38, 277) were selected from the 400 seedlings resulted from crossing of the $P$. tremula $\times$ P. tremuloides clone L 40 with P. tremula L 311 (Table 3). All of these plants showed a good growth performance five months after sowing. They were established in vitro and propagated for the outdoor container test (see below). In the following year, two triploid plants were selected from 372 seedlings obtained after crossing L 40 with ARB 2M. In vitro cultures of both well growing plants were established for propagation and later testing.

Intersectional crossbreeding was performed to combine benefits of intersectional hybridization with those derived from triploidisation. A prerequisite for carrying out intersectional crossbreeding is the selection of parent clones with high performance and special characteristics like excellent growth and resistance properties, good rooting ability of cuttings and wood quality. The two $P$. deltoides (Eastern cottonwood) clones, S 39 and S 13, (section Aigeiros) and the P. tremula x P. tremuloides clone L 328 (section Populus) are characterised by a high growth performance. The clone "Androscoggin“ (section Tacamahaca) possesses distinguished resistance properties, and the clone $P$. simonii Sim1 is characterised by a strong drought resistance and its excellent rooting ability.

The first intersectional crossing was performed using L 328 and $P$. deltoides S 13 as parents. The poplar sections Populus and Aigeiros are generally considered to be difficult to combine or even incompatible (ECKENWALDER, 1996). However, use of hybrid aspen as the 
Table 2. - In vitro pollination experiments.

\begin{tabular}{|c|c|c|}
\hline Crossing combination & $\begin{array}{c}\text { Pollen-treatment/ } \\
\text { year of } \\
\text { pollination }\end{array}$ & $\begin{array}{l}\text { Triploid plants } \\
\text { obtained }\end{array}$ \\
\hline L $40 \times$ L $2[(P$. tremula $\times$ P. tremulordes $) \times P$. tremula $]$ & heat $/ 2009$ & L $40 \times$ L 2 "Tripi" \\
\hline L $40 \times$ L $311[(P$. tremula $\times$. trentuloides $) \times P$, tremula $]$ & sieving $/ 2010$ & L $40 \times$ L 311 "Trio" \\
\hline ARB $4 \times$ ARB $2 \mathrm{M}[(P$. tremula $\times P$. tremuloides $) \times(P$. tremula $\mathrm{x}$ & sieving/2010 & $\mathrm{ARB} 4 \mathrm{x}$ ARB $2 \mathrm{M}$ \\
\hline P. tremuloides)] & & No. 1 \\
\hline L $40 \times$ L $311[(P$. tremula $\times$ P. trentuloides $) \times P$. tremula $]$ & sieving/2011 & L $40 \times$ L 311 No. 2 \\
\hline L $328 \times 4449$ No. I [(P. tremula $\times$ P. tremuloides $) \times$ P. $\times$ canescens $]$ & sieving/2011 & L $328 \times$ L 449 No. I \\
\hline L $40 \times \mathrm{L} 454$ No. 1 [(P. tremula $\times P$, remuloides $) \times P . \times$ canescens $]$ & sicving/2012 & L $40 \times$ L 454 No. 1 \\
\hline
\end{tabular}

female parent could result in a broader acceptance of pollen from poplars of other sections as already suggested by RoNALD (1982). Among the heterogeneous offspring individuals (27 plants) obtained from this crossing, there was one triploid plant, but with only insufficient growth. The $P$. deltoides clone S 39 was used as mother tree in two intersectional crossings with the clones "Androscoggin" and P. simonii Sim1 (both belonging to the section Tacamahaca) in two consecutive years. From the 350 seedlings resulted from the first crossing, four triploid plants could be selected in 2011. The two largest triploid plants (No. 152 and No. 314) were established in vitro and propagated for the container test (see below). From the 343 seedlings obtained from the combination $P$. deltoides $\mathrm{S} 39 \times P$. simonii Sim1, ten triploid plants were selected in 2012. The plants showed a very different growth performance. Five months after sowing, the largest two individuals had sprout heights of 45 and $48 \mathrm{~cm}$, respectively, while the others ranged from $22 \mathrm{~cm}$ to $35 \mathrm{~cm}$. The six largest triploid plants were established in vitro and propagated for later testing.

In general, the recovery of triploids obtained after crossbreeding using enriched diploid pollen ranged from
0.5 to $3.7 \%$ per total number of plants tested by flow cytometry and depended on the clone used. All in all, crossbreeding using enriched diploid pollen seems to be more effective than in vitro pollination. The total amount of triploid plants that could be produced demonstrate the suitability of this approach for breeding triploids by crossing aspen as well as in intersectional hybridizations.

In other studies, the proportion of artificially induced diploid pollen could enrich up to $80 \%$ (ZHANG and LI, 1992; KANG et al., 1999), however, the rate of triploid plants derived from the respective crossings was also relatively low. In vivo germination performed in stigmata revealed a later germination and slower pollen tube growth of diploid pollen compared to haploid pollen, suggesting a weaker fertilization ability of diploid pollen (KANG and ZHU, 1997). KANG et al. (2000) used the higher radiation sensitivity of haploid pollen, but the results were not yet satisfactory. It remains open, how higher rates of triploid plants can be obtained in crossbreeding.

A problem in the vegetative propagation of aspen, especially the $P$. tremula clones, is the insufficient rooting ability of hardwood cuttings compared to poplars of, for

Table 3. - Crossbreeding experiments in the greenhouse.

\begin{tabular}{|c|c|c|c|c|}
\hline Crossing combinations & $\begin{array}{c}\text { Number of } \\
\text { triploid } \\
\text { plants }\end{array}$ & $\begin{array}{l}\text { Pollen- } \\
\text { treatment }\end{array}$ & $\begin{array}{l}\text { Year of } \\
\text { sclection }\end{array}$ & Crossing between sections \\
\hline $\begin{array}{l}\mathrm{L} 328 \times \mathrm{S} 13 .[(P . \text { tremula } \times \text { P. Iremuloides }) \times \\
\text { P. deltoides }]\end{array}$ & 1 & sicving & 2009 & Populus x Aigeiros \\
\hline $\begin{array}{l}\text { L } 290 \times \mathrm{L} 9[(P . \text { tremula } \times \text { P. tremuloides }) \times \\
P . \text { tremula }]\end{array}$ & 0 & colchicine & 2009 & Populus $x$ Popultus \\
\hline L $316 \times$ L $9(P$. tremula $\times$ P. tremula $)$ & 0 & heat & 2009 & Populus $x$ Populus \\
\hline $\begin{array}{l}\mathrm{L} 40 \times \mathrm{L} 311[(P . \text { tremula } \times \text { P. tremuloides }) \times \\
\text { P. tremula }]\end{array}$ & 3 & sieving & 2011 & Populus $\times$ Populus \\
\hline $\begin{array}{l}\mathrm{S} 39 \times \text { "Androscoggin" }[P \text {, deltoides } \mathrm{x} \\
(P, \text { maximowiczit } \mathrm{x} P \text {. trichocarpa })]\end{array}$ & 4 & sieving & 2011 & Aigeiros $\mathrm{x}$ Tacamahaca \\
\hline $\begin{array}{l}\mathrm{L} 40 \times \mathrm{ARB} 2 \mathrm{M}[(P . \text { tremula } \times P . \text { tremuloides }) \\
\times(P . \text { tremula } \times \text { P.tremuloides })]\end{array}$ & 2 & sieving & 2012 & Populus $\times$ Populus \\
\hline S $39 \times \mathrm{P} . \operatorname{sim} 1(P$. delloides $\times P$ simonii) & 10 & sieving & 2012 & Aigeiros x Tacantahaca \\
\hline
\end{tabular}


example, section Tacamahaca (OKORO and GRACE, 1976; HARTMANN et al. 2002). In preliminary investigations, the possibility of transferring rooting ability by crossing aspen with poplar clones was shown on a diploid hybrid plant derived from crossing $P$. tremula $\times$ P. tremuloides L 290 × P. pseudosimonii Pps1 (Populus x Tacamahaca). The clone was micropropagated, and cuttings obtained from one-year-old plants could be rooted successfully (data not shown). In this study, pollen of the Chinese clone $P$. simonii Sim 1 was used in order to transfer the excellent rooting ability from the section Tacamahaca to triploid plants. This is of particular relevance for cultivation in medium rotation plantations especially under poor soil conditions and limited water supply.

With the start of selecting triploids from crossbreeding in the greenhouse in 2009, some plants with outstanding growth of about $20 \%$ higher stem height compared with the total progeny were found within the offspring of the crossings of L 316 and L 290 with L 9 (Table 3). Investigation by flow cytometry showed two fluorescence signals, suggesting that these plants are mixoploid (diploid-tetraploid), containing cells with different ploidy levels $(2 \mathrm{n}=38$ and $4 \mathrm{n}=76)$ with predominantly diploid cells. The origin of this ploidy level is not clear yet, however it was stable over several years now.
Mixoploidy is a well-known characteristic in which the tissue is composed of cells with different ploidy level (RANJBAR et al., 2011). The origin of mixoploids may either be spontaneous or induced and it is often associated with the occurrence of polyploidy or hybridization or with the impact of chemicals (PAGLIARINI, 2000). In most cases, mixoploidy is caused by meiotic abnormalities, but a clear explanation for the genesis and about the nature of this condition can not be given yet. Some studies suggested positive effects of mixoploidy on plant growth and stress tolerance especially under extreme conditions (KunAKH et al., 2008; SivolAPOV and BlAGODAVORA, 1994).

\section{Initial studies of growth performance of the triploid plants}

In order to estimate the performance of the triploid clones under outdoor conditions, selected clones generated in 2009-2011 were tested in a container test in comparison to aspen clones known for their high growth performance. In total, two triploid clones from in vitro pollination and five from crossbreeding in the greenhouse were studied. Additionally, two mixoploid clones obtained from crossings using induced diploid pollen of $P$. tremula clone L 9 were included. As a reference, three
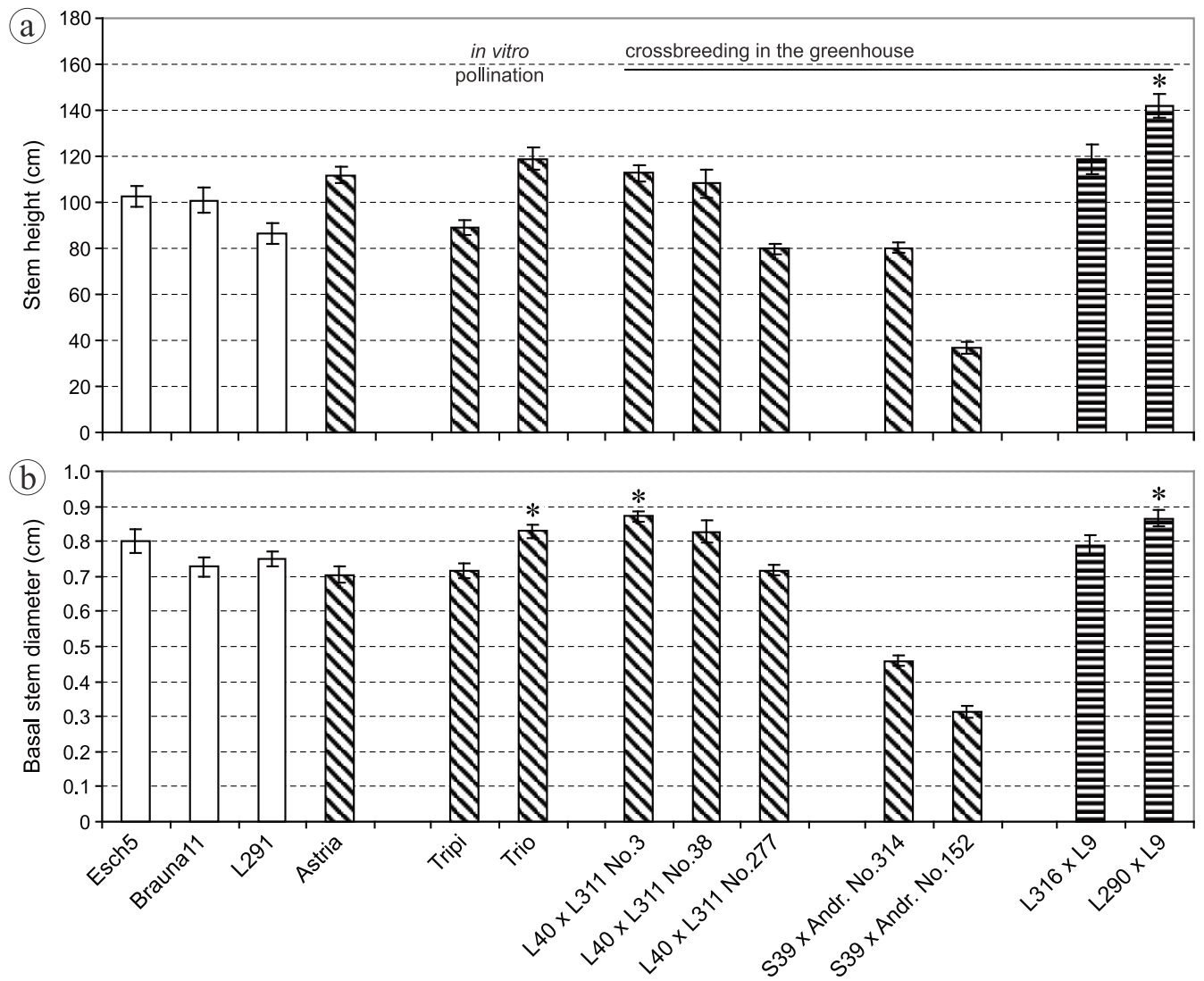

Figure 4. - Stem height (a) and basal stem diameter (b) of triploid and mixoploid clones obtained from in vitro pollination and crossbreeding in the greenhouse in comparison to reference clones. The hatched columns represent the triploid and the striped columns the mixoploid clones. Three fast-growing diploid aspen clones (white) and the triploid clone "Astria" were used as a reference. Asterisk (*) mark statistically significant increases compared to the control "Astria“ (Dunn's method, $\mathrm{p}<0.05)$. Error bars indicate the standard error of means. 
diploid fast-growing aspen clones, as well as the triploid clone "Astria", were used.

Overall, the generated triploid plants showed a broad variation in growth (Fig. 4). The clone "Trio", derived from in vitro pollination, had a stem height comparable to the clone "Astria". Moreover, the basal stem diameter was significantly increased. Whereas the clone "Tripi" did almost reach the height of the clone "Astria" in a previous container test in 2010 (data not shown), it brought a distinctly worse result in 2012 . The lower performance was probably caused by the increased susceptibility of this clone to insect attacks and subsequent fungal infections. Furthermore, the clone "Tripi" was proved to be frost-sensitive $\left(-25^{\circ} \mathrm{C}\right)$ in the first winter period.

The best triploid clone from the crossbreeding in the greenhouse up to now was L 40 x L 311 No. 3, which had a significantly higher BSD in comparison to "Astria" (Fig. 4b). The growth property of clone L $40 \times$ L 311 No. 277, despite deriving from the same combination, was poor.

The two triploid plants from the intersectional crossing S 39 x "Androscoggin" differed in their growth, but both were only moderate in their properties. Apart from the slow growth, the long growing cycle and their high resistance to animal pests, compared with the other clones, was remarkable.

The mixoploid clone L 290 x L 9 showed the best results in the container test and had significantly increased shoot height and BSD as compared to the control "Astria" (Fig. 4). Together with the other mixoploid clone L $316 \times$ L 9, they were also among the best growing clones in the previous container test in 2010 (data not shown). Fast-growing mixoploid poplar plants were already reported previously (SIVOLAPOV and BLAGODAVORA, 1994). Whether the growth characteristics are due to their mixoploid state is not yet clear, nor is how long this state will be stable over time.

All in all, the clones L 40 x L 311 No. 3 and No. 38 from crossbreeding in the greenhouse and the clone "Trio", which derived from the same combination but was produced by in vitro pollination, displayed the best growth performance of the generated triploid clones. However, the results also showed that triploid plants displayed a broad variation in their growth performance. Even if they derive from the same combination or crossbreeding, plants often showed very different characteristics. Our results demonstrated that not every triploid plant is a fast-growing plant, but among triploid plants, individuals often show excellent growth characteristics. This is in agreement with studies of ZHU et al. (1997) on triploids of $P$. tomentosa, who selected three fast-growing plants (increase of up to $255 \%$ compared to the diploid control) out of twenty triploid clones obtained after pollination with unreduced pollen. The high variability in growth among our triploids proved again that selection is a necessary tool for the genetic improvement of triploid poplar collections. Selection within triploid populations seems likely to be more effective than diploid selection because triploid populations may contain extra genetic variation owing to dosage effect from chromosome doubling, heterosis from hybridization, accumulation of more polymicrogenes and other factors (ZHU et al., 1997).

Not only the growth performance of triploid trees is important but also other characteristics like wood quality, fibre length and amount of cellulose. Longer wood fibre lengths of triploid in comparison to diploid trees, which are especially important for the paper industry, have been demonstrated in different poplar species (VAN BuIJTENEN et al., 1958; BRADSHAW and STETTLER, 1993; ZHU et al., 1998).

Field trials need to be repeated in the next years with the aim to prove the growth performance of these clones over a longer period of time. Further work will be focussed on testing other characteristics like fibre length, frost resistance, tolerance against biotic and abiotic stress factors and transfer of rooting ability.

\section{Conclusions}

This study showed that the pollination using pollen fractions containing an increased proportion of diploid pollen grains is suitable to produce triploid plants. Both methods used for transfer of pollen, the in vitro pollination as well as crossbreeding in the greenhouse were successful, but the second approach was more effective and easier to apply. Due to the high variability of triploid plants, the subsequent selection of suitable clones is of crucial importance for the breeding of fastgrowing plants with improved characteristics.

The production of triploid intersectional hybrids using diploid pollen is aimed at the possibility to improve resistance and tolerance characteristics and to transfer the rooting capacity of shoot cuttings to the progeny in combination with the properties of triploidisation.

\section{Acknowledgments}

The work was supported by the Agency for Renewable Resources e.V. (FNR) within the framework of the project FastWOOD FKZ: 22011107. We would like to thank Volker SchneCK and Dr. MiRko Liesebach for providing poplar clones. The help of Chinese colleagues Prof. Minsheng Yang (Hebei Agricultural University) and Prof. Xiangyang Kang (Beijing Forestry University) in providing pollen from Asian poplars is kindly acknowledged. We are grateful to Hannelore Enkisch for her excellent technical assistance.

\section{References}

Adler, P. R., S. J. Del Grosso and W. J. Parton (2007): Life-cycle assessment of net greenhouse-gas flux for bioenergy cropping systems. Ecol Applic 17: 675-691.

BAumeister, G. (1980): Beispiele der Polyploidie-Züchtung. AFZ 26: 340-343.

Bradshaw, H. D. and R. F. Stettler (1993): Molecular genetics of growth and development in Populus. I. Triploidy in hybrid poplars. Theor Appl Genet 86: 301-307.

Bretagnolle, F. and J. D. Thompson (1995): Gametes with the somatic chromosome number: mechanisms of their formation and role in the evolution of autoploid plants. New Phytol 129: 1-22. 
CAI, X. and X. Y. KANG (2011): In vitro tetraploid induction from leaf explants of Populus pseudo-simonii Kitag. Plant Cell Rep 30: 1771-1778.

De La Torre Ugarte, D. G., M. E. Walsh, H. Shapouri and S. P. SLINSKY (2003): The economic impacts of bioenergy crop production on U.S. agriculture. U.S.D.A. Office of Chief Economist, Office of Energy Policy and New Uses. Rpt. No. 816, 41p.

De Storme, N. and D. Geelen (2011): The Arabidopsis mutant Jason produces unreduced First Division Restitution male gametes through a parallel/fused spindle mechanism in Meiosis II. Plant Physiol 155: 1403-1415.

Dewitte, A., K. Van Laere and J. Van Huylenbroeck (2012): Use of $2 \mathrm{n}$ Gametes in Plant Breeding. pp. 59-86. In: Plant Breeding, edited by I.Y. ABDURAKHMONOV, www.intechopen.com.

ECKENWALDER, J. E. (1996): Systematics and evolution of Populus. pp. 7-32. In: Biology of Populus and its implications for management and conservation, edited by R. F. Stettler, H. D. Bradshaw JR., P. E. Heilmann and T. M. HiNCKLEY, NRC Research Press, National Research Council of Canada, Ottawa.

Einspahr, D. W., J. P. VAN BuiJtenen and J. R. Peckham (1963): Natural variation and heritability in triploid aspen. Silvae Genet. 12: 51-58.

EINSPAHR, D.W. and L. L. WinTON (1976): Genetics of quaking aspen. Aspen Bibliography, Paper 5026. http: //digitalcommons. Usu.edu/aspen_bib/5026.

EINSPAHR, D.W. (1984): Production and utilisation of triploid hybrid aspen. Iowa State J. Res. 58: 401-409.

EverY, D. A. and D. Wiens (1971): Triploidy in Utah aspen. Madrono: 138-47.

Ewald, D., K. Ulrich, G. NAujoKs and M. B. Schröder (2009): Induction of tetraploid poplar and black locust plants using colchicine: chloroplast number as an early marker for selecting polyploids in vitro. Plant Cell Tiss Organ Cult 99: 353-357.

EwALD, D. and K. UlRICH (2012): In vitro pollination in poplar of section Populus. Plant Cell Tiss Organ Cult 111: $255-258$.

HaRlan, J. R. and J. M. J. De Wet (1975): On Ö. Winge and a prayer: The origins of polyploidy. Bot Rev 41: 361-390.

Hartmann, H. T., D. E. Kester, F. T. Davies JR. and R. L. Geneve (2002): Hartmann and Kester's plant propagation: principles and practices. $7^{\text {th }}$ ed. Pearson education, New Jersey. ISBN 0-13-679235-9.

HEILBORN, O. (1934): On the origins and preservation of polyploidy. Hereditas 19: 233-242.

HERRMANN, S. (1976): Verfahren zur Konservierung und Erhaltung der Befruchtungsfähigkeit von Waldbaumpollen über mehrere Jahre. Silvae Genet 25: 223-229.

Janssen, A., S. Fehrenz, C. Fey-Wagner and W. Hüller (2012): Züchtung von Schwarz- und Balsampappeln für den Kurzumtrieb, pp. 33-54. In: Züchtung und Ertragsleistung schnell wachsender Baumarten im Kurzumtrieb. Beiträge aus der Nordwestdeutschen Forstlichen Versuchsanstalt, Universitätsverlag Göttingen.

Johnsson, H. and C. EkLUNDH (1940): Colchicine treatment as a method in breeding hardwood species. Svensk Papp Tidn 43: 373-377.

KANG, X. Y. and Z. T. ZHU (1997): A study on the 2n pollen vitality and germinant characteristics of white populus. Acta Bot Yunnanica 19: 402-406.

KANG, X. Y., Z. T. ZHU and H. B. LIN (1999): Study on the effective treating period for pollen chromosome doubling of $P$. tomentosa x P. bolleana. Sci Silvae Sin 35: 21-24.
KANG, X. Y., Z. T. ZHU and H. B. LIN (2000): Radiosensitivity of different ploidy pollen in poplar and its application. Acta Genet Sinica 27: 78-82.

KANG, X. Y., Z. T. ZHU and Z. Y. ZhANG (2000a): Suitable period of high temperature treatment for $2 \mathrm{n}$ pollen of Populus tomentosa x P. bolleana. J Beijing For Univ 22 . $1-4$.

KANG, X.Y. (2002): Mechanism of $2 \mathrm{n}$ pollen occurring in Chinese white poplar. J Beijing For Univ 24: 67-70.

KANG, X.Y., J. ZHANG, P. D. ZHANG and Y. H. LI (2006): Induction of triploids in white poplar, pp. 71. In: International Poplar Symposium IV, Nanjing.

Kunakh, V. A., V. I. Adonin, S. P. Ozheredov and Y. B. BLYUM (2008): Mixoploidy in wild and cultivated species of Cruciferae capable of hybridizing with rapeseed Brassica napus. Cytol Genet 42: 204-209.

LI, Y. H., X. Y. KANG, S. D. WANG, Z. H. ZhANG and H. W. Chen (2008): Triploid induction in Populus alba $\mathrm{x}$ $P$. glandulosa by chromosome doubling of female gametes. Silvae Genet 57: 37-40.

LiEsebaCH, H., G. NAUjoKs and D. Ewald (2011): Successful hybridisation of hybrid aspen (Populus tremula $\mathrm{x}$ $P$. tremuloides) and eastern cottonwood (P. deltoides). Sex Plant Reprod 24: 189-198.

Linsmaier, E. M. and F. Skoog (1965) Organic growth factor requirements of tobacco tissue culture. Plant Physiol 21: 487-492.

LIU, G., Z. LI and M. BAO (2007): Colchicine-induced chromosome doubling in Platanus acerifolia and its effect on plant morphology. Euphytica 157: 145-154.

Mashkina, O. S., I. M. Burdaeva, M. M. Belozerova and L. N. V'YunOva (1989) A method of inducing diploid pollen in woody species. Lesovedenie 1: 19-25.

Mock, K. E., C. M. Callahan, M. N. Islam-Faridi, J. D. SHAW, H. S. RAI and S. C. SANDERSON et al. (2012): Widespread Triploidy in Western American Aspen (P. tremuloides). PLoS ONE 7 (10): e48406.

MüntZing, A. (1936): The chromosomes of a giant Populus tremula. Hereditas 21: 383-393.

Nilsson-Ehle, H. (1936): Note regarding the gigas form of Populus tremula found in nature. Hereditas 21: 372-82.

OrJedA, G., R. FReYRE and M. Iwanaga (1990): Production of $2 \mathrm{n}$ pollen in diploid Ipomoea trifida, a putative wild ancestor of sweet potato. J Hered 81: 462-467.

Okoro, O. O. and GRACE, J. (1976): The physiology of rooting Populus cuttings. I. Carbohydrates and Photosynthesis. Physiol Plant 36: 133-138.

ORTIZ, R. (1997): Occurrence and inheritance of $2 \mathrm{n}$ pollen in Musa. Ann Bot 79: 449-453.

PAgliarini, M. S. (2000): Meiotic behaviour of economically important plant species: the relationship between fertility and male sterility. Genet Mol Biol 23: 997-1002.

Perlack, R. D., L. L. Wright, A. F. Turhollow, R. L. Graham, B. J. Stokes and D. C. Erbach (2005): Biomass and feedstockfor a bioenergy and Bioproducts industry: The technical feasibility of a billion-ton annual supply. Oak Ridge National Laboratory, Oak Ridge, TN.

RANJBAR, M., R. KARAMiAn and S. NouRI (2011): Diploidtetraploid mixoploidy in a new species of Astragalus (Fabaceae) from Iran. Ann Bot Fennici 48: 343-351.

R CORE TEAM (2013): R: A language and environment for statistical computing. R Foundation for Statistical Computing, Vienna, Austria. ISBN 3-900051-07-0, Available at: http://www.R-project.org/. 
Riemenschneider, D. E., W. E. Berguson, D. I. Dickmann, R. B. Hall, J. G. Isebrands, C. A. Mohn, G. R. Stanosz and G. A. TUSKAN (2001): Poplar breeding and testing strategies in the north-central ANDS.: Demonstration of potential yield and consideration of future research needs. The Forestry Chronicle 77: 245-253.

RoNALD, W. G. (1982): Intersectional hybridization of Populus sections, Leuce-Aigeiros and Leuce-Tacamahaca. Silvae Genet 31: 94-99.

SAX, K. (1936): The experimental production of polyploidy. J Arnold Arbor 17: 153-59.

Schenk, R. U. and A. C. Hildebrandt (1972): Medium and techniques for induction and growth of monocolyledonous and dicotyledonous plant cell cultures. Can J Bot 50: 199-204.

Schlarbaum, S. E. (1991): Cytogenetics of forest tree species, pp. 593-618. In: Chromosome engineering in plant genetics and breeding, edited by T. TSUCHIYA and P. K. GuPTA, Elsevier Publ., Netherlands.

Sivolapov, A. and T. A. Blagodarova (1994): Different levels of mixoploidy in hybrid poplars, pp. 311-316. In: Cytogenetic studies of forest trees and shrub species, edited by Z. BorZAN and S. E. Schlarbaum, Proceedings of the first IUFRO Cytogenetics Working Party, September 8-11, 1993 Brijuni National Park Croatia.

SkIEBE, K. (1965): Die Entstehung von polyploiden Populationen in der Evolution. Deutsch Landw (Berlin) 16: 340-343

Stanton, B., J. Eaton, J. Johnson, D. Rice, B. Schuette and B. Moser (2002): Hybrid poplar in the Pacific Northwest: The effects of market-driven management. J For 100: 28-33.

Stanton, B. J., D. B. Neale and S. Li (2010): Populus Breeding: From the classical to the genetic approach, pp. 309-312. In: Genetics and Genomics of Populus, Plant Genetics and Genomics: Crops and Models 8, edited by S. JANSSON et al. Springer Science+Business Media, DOI 10.1007/978-1-4419-1541-2_14.

TANG, Z. Q., D. L. Chen, Z. J. Song, Y. C. He and D. T. CAI (2010): In vitro induction and identification of tetraploid plants of Paulownia tomentosa. Plant Cell Tiss Organ Cult 102: 213-20.
VÄINÖLÄ, A. (2000): Polyploidization and early screening of Rhododendron hybrids. Euphytica 112: 239-44.

VAn BuiJtenen, J. P., P. N. Joranson and D. W. Einspahr (1957): Naturally occurring triploid quaking aspen in the United States. Proc Soc Am Foresters: 62-64.

VAN BuiJTEnen, J. P., P. N. Joranson and D. W. Einspahr (1958): Diploid versus triploid aspen as pulpwood sources with reference to growth, chemical, physical, and pulping differences. TAPPI J 41: 170-175.

Veilleux, R., N. A. McHale and F. I. Lauer (1982): $2 \mathrm{n}$ gametes in diploid Solanum: frequency and type of spindle abnormalities. Can J Genet Cytol 24: 301-314.

WANG, J., X. KANG, D. Li, H. ChEN and P. ZhANG (2010): Induction of diploid eggs with colchicine during embryo sac development in Populus. Silvae Genet 59: 40-48.

WANG, J., D. L. Li and X. Y. KANG (2012): Induction of unreduced megaspores with high temperature during megasporogenesis in Populus. Ann For Sci 69: 59-67.

WRIGHT L. L. (1994): Production technology status of woody and herbaceous crops. Biomass and Bioenergy 6 : 191-209

XI, X. J., X. B. JiAnG, D. Li, L. Q. Guo, J. F. Zhang, Z. Z. WEI and B.L. LI (2011): Induction of $2 \mathrm{n}$ pollen by colchicine in Populus $\mathrm{x}$ popularis and its triploids breeding. Silvae Genet 60: 155-60.

YAO, C. L. and J.W. PU (1998): Timber characteristics and pulp properties of the triploid of Populus tomentosa. J Beijing For Univ 20: 18-21.

ZHANG, Z. Y. and F. L. Li (1992): The techniques of pollen chromosome doubling of Populus tomentosa. J Beijing For Univ 14: 52-58.

ZHANG, Z. and X. KANG (2010): Cytological characteristics of numerically unreduced pollen production in Populus tomentosa-Carr. Euphytica 173: 151-59.

ZHU, Z., X. KANG and Z. ZHANG (1997): Advances in the triploid breeding program of Populus tomentosa in China. J Beijing For Univ 6: 1-8.

ZHU, Z., X. Y. KANG and Z. ZHANG (1998): Studies on selection of natural triploids of Populus tomentosa. Sci Silvae Sin 34: 22-31. 